\title{
Effect of Transglutaminase Enzyme and some Natural Antioxidants on the Quality of Ready to Eat Catfish Fingers during Frozen Storage
}

\author{
Samar Aref ${ }^{1 *}$; Noha Morsy ${ }^{2}$; Ramadan A. Habiba ${ }^{1}$ and F. M. Zayat ${ }^{1}$ \\ ${ }^{1}$ Department of Food Science \& Technology, Faculty of Agriculture, Suez Canal University, Ismailia, Egypt \\ ${ }^{2}$ Department of Food Science \& Technology (Home Economics), Faculty of Agriculture, Suez Canal University, \\ Ismailia, Egypt
}

Received: 2/9/2016

\begin{abstract}
To increase the utilization of catfish, ready to eat fish fingers were prepared and evaluated during frozen storage at $-18^{\circ} \mathrm{C}$ for 5 months. The effect of transglutaminase enzyme, date seed powder, citric acid and ascorbic acid, added individually or in combination, on physical, chemical, microbiological and sensory properties were investigated. The obtained results indicated that $\mathrm{pH}, \mathrm{TVB}-\mathrm{N}, \mathrm{TMA}, \mathrm{FFA}, \mathrm{PV}$ and TBA were decreased significantly $(\mathrm{P} \leq 0.05)$ in the treated fish finger samples compared to the control. Also, the applied natural antioxidants retarded the microbial growth (aerobic plate count, pseudomonas and Enterobacteriaceae counts) during storage period as the treated samples gave better results compared to the control sample. Also, sensory evaluations (color, odor, taste, texture and overall acceptability) indicated that such natural treatments improved sensory scores of the prepared fingers during frozen storage in comparison with the control sample.
\end{abstract}

Keywords: Ready to eat fish fingers, transglutaminase enzyme, date seed powder, citric acid, ascorbic acid

\section{INTRODUCTION}

The consumption and popularity of fish and seafood have increased during recent years (Bochi et al., 2008) due to the increase in consumption rate by the increasing world population and awareness on nutritional value of fishery products (Emborg et al., 2001). Fish and fishery products contain proteins of high quality, and high content of unsaturated fatty acids, especially the n-3 PUFAs (Venugopal and Shahidi, 1995). An adequate consumption of n-3 PUFAs can help to protect humans against many adverse health effects, including mortality due to coronary heart disease (CHD), and cancer (Colombo et al., 2004; Iso et al., 2006). These products are important in the prevention of cardiovascular and inflammatory diseases and may have a promising effect on the prevention of cognitive decline and dementia in older people (Simopoulos, 1999; Sinn et al., 2012).

Catfish (Clarias gariepinus) is a highly nutritious that contain high amounts of unsaturated fatty acids, vitamins, proteins, and minerals (Nelson, 2006). Catfish is referred to as a fatty fish when compared to other fish species and it is also classified as dark muscle fish with strong muddy odor, hence all these characteristics have slightly hindered its wide utilization (Tadpitchayangkoon and Yongsawatdigul, 2009). Therefore, it is important to increase the palatability and economic value for such fish species. Recently, changes in life style and nutritional awareness resulted in increasing consumption of ready-to-eat foods (Cakli et al., 2005). Fish fingers, as battered and breaded products, are stored and distributed in the frozen state.

Oxidation of lipids occurred during raw material storage, processing, heating and distribution. Storage is one of the basic processes that cause rancidity in food products. Consequently, it may affect flavour, texture, taste, and shelf-life of fish products and their nutritional quality (Banerjee, 2006; Babovic et al., 2010; Karakaya et al., 2011). Antioxidant addition is one of the effective ways to prolong shelf-life and preserve the quality of food (Serdaroğlu and Felekoglu, 2005). Thus, the demand for novel natural antioxidants has rocketed due to health effects and to avoid possible adverse side effects of synthetic antioxidants as reported by Benjakul et al. (2005) and Sarkardei and Howel (2008).

Transglutaminase enzyme (MTGase) is able to catalyze the cross linking of many proteins such as whey proteins, soy proteins, wheat proteins, beef myosin, casein and actomyosin, leading to affect their texture (Motoki and Seguro, 1998). It also affects changes in solubility, emulsifying capacity, foaming and gelation properties of proteins. Moreover it enhances the firmness, elasticity, viscosity, and water binding capacity of many foods (Giosafatto et al., 2012).

Date seeds or pits, a waste product, are generally resulted from date factories producing pitted dates, syrup, juice, and jams (Rahman et al., 2007). Date seeds are a good source of total phenolics which is considered as a cheap source of natural antioxidants. Therefore, date seed powder can be used to produce functional foods (Al-Farsi et al., 2007; Ammar and Habiba, 2010).

Ascorbic acid (AA), citric acid (CA) and their salts are used in the food industry as chelators and acidulants (Kim et al., 2006). They revealed a partial inhibition of primary and secondary lipid oxidation during storage at freezing temperature of catfish fillets (Pourashouri et al., 2009), and a combination of both acids resulted in a much better lipid oxidation retardation in frozen horse mackerel than the individual acids (Aubourg et al., 2004).

The objective of the present study was to determine the effects of transglutaminase, date seed powder, citric and ascorbic acids on chemical, microbiological and sensory quality of ready to eat fish fingers using catfish fillet.

\section{MATERIALS AND METHODS}

Catfish (Clarias gariepinus), weighting between 1 and $2 \mathrm{~kg}$ each, were obtained directly from the fish market (Ismailia, Egypt) in November, 2013. 
Date seed powder was prepared from a common local date fruits (Samany variety). Wheat and corn flours, sugar, salt, cumin, onion, garlic powder, pepper and thyme were purchased from local supermarket, while transglutaminase enzyme was purchased from Ajinomoto (Tokyo, Japan). Citric and ascorbic acids and other chemicals were of food grades.

\section{Date seed powder preparation}

Date fruits (Samany variety) were purchased from local market and then pitted and pits were dried in an oven at $70^{\circ} \mathrm{C}$ overnight, milled by a grinder (Moulinex, LM2421, France) to pass through $1 \mathrm{~mm}$ sieve, packed and stored at $4^{\circ} \mathrm{C}$ until used in the experiments as an additive (Ammar and Habiba, 2010).

\section{Preparation of fish fingers}

About $40 \mathrm{~kg}$ of catfish was beheaded, gutted, washed and filleted. The fillets were minced using a meat mincer through a plate with $3 \mathrm{~mm}$ diameter holes. The control mince included $93.5 \%$ catfish mince, $1.5 \%$ salt, $1 \%$ sugar, $3 \%$ wheat flour, $0.243 \%$ each of cumin, onion, garlic powder, pepper and $0.020 \%$ thyme according to Tokur et al. (2006). All ingredients were mixed and homogenized by a kitchen blender. The mix was divided into six equal parts to prepare the experimental treatments. Each part was transferred to a commercial mixer, where they were mixed with tested additives except for one part, which served as the control (T1). Transglutaminase enzyme was added at a concentration of $0.5 \%$, (T2). Date seed powder was used at a level of $1 \%$ (T3). A combination of citric acid and ascorbic acid $0.5 \%$ each, (T4). Also, a combination of the enzyme $(0.5 \%)$ and date seed powder $(1 \%)$, (T5); and a combination of the enzyme $(0.5 \%)$ and the mixture of citric and ascorbic acids $(0.5 \%+0.5 \%)$ were used, (T6). Then, all fish finger treatments were manually shaped. Only treatment samples containing transglutaminase enzyme were incubated at $40{ }^{\circ} \mathrm{C}$ for 30 min after forming. Fish fingers were well battered using a mixture of wheat flour, corn flour and cold water at 30,10 and $60 \%$, respectively. Then, it was covered with traditional bread crumb and finally the prepared fish finger samples were flash fried for half a minute at 180 ${ }^{\circ} \mathrm{C}$ in a fryer containing sunflower oil according to Cakli et al. (2005) and Tokur et al. (2006). Then, the samples were drained and allowed to be cooled. The fried samples were packaged in a foam plate, wrapped with cling film, and stored in a freezer at $-18{ }^{\circ} \mathrm{C}$ for five months.

\section{Proximate composition}

Moisture content of samples was determined using oven at $105^{\circ} \mathrm{C}$ until constant weight, while, ash was measured at $550^{\circ} \mathrm{C}$ (AOAC, 2000). Micro-kjeldahl method was used to determine sample crude protein, and a factor of 6.25 was applied (AOAC, 2000). For the determination of crude fat, the method of Bligh and Dyer (1959) was used, by subjecting the sample to extraction with a mixture of chloroform and methanol (1:2 v:v). Total carbohydrates were determined by subtracting the sum of $\%$ moisture $(\mathrm{M})$, fat $(\mathrm{F}), \%$ crude protein $(\mathrm{CP})$ and $\%$ ash content $(\mathrm{A})$ from $100 . \%$ Total carbohydrates $=100-(\mathrm{M}+\mathrm{F}+\mathrm{CP}+\mathrm{A})$.

\section{Physical and chemical parameters}

Texture of prepared fish fingers was determined using Y2 laboratory penetrometer and the results were expressed as $\mathrm{kg} / \mathrm{cm}^{2}$. The $\mathrm{pH}$ values were determined in the homogeneous mixtures of fish and distilled water (1:9, w:v), using standardized $\mathrm{pH}$ meter (Jenway 3010; UK). Total volatile basic-nitrogen (TVB-N) was measured by steam-distillation of the TCA-fish extract using the modified method of Malle and Tao (1987). Trimethylamine (TMA) content was determined using Malle and Poumeyrol (1989) method. Peroxide value (PV) and free fatty acid (FFA) contents were determined in the lipid extract by the Egan et al. (1997) method. Thiobarbituric acid reactive substances (TBARS) value as $\mathrm{mg}$ malonaldehyde $/ \mathrm{kg}$ was determined using a spectrophotometric method (Tarladgis et al., 1960).

\section{Antioxidant activity of date seed powder}

The antioxidant activity of date seed powder sample was determined by DPPH method (Lee et al., 2003) with some modifications. The stock reagent solution $\left(1 \times 10^{-3} \mathrm{M}\right)$ was prepared by dissolving $22 \mathrm{mg}$ of DPPH in $50 \mathrm{~mL}$ of methanol and stored at $-20{ }^{\circ} \mathrm{C}$ until use. The working solution $\left(6 \times 10^{-5} \mathrm{M}\right)$ was prepared by mixing $6 \mathrm{~mL}$ of stock solution with $100 \mathrm{~mL}$ of methanol to obtain an absorbance value of $0.8 \pm 0.02$ at $515 \mathrm{~nm}$, measured using a spectrophotometer (6505 UV/Vis, Jenway Ltd., Felsted, Dunmow, UK). Extracts each of $0.1 \mathrm{ml}$ were mixed with $3.9 \mathrm{ml}$ of DPPH solution for 30 $\mathrm{s}$ and left to react for $30 \mathrm{~min}$. Then, the absorbance (A) at $515 \mathrm{~nm}$ was recorded. A control was also done using the extraction solvent.

Scavenging activity $(\%)=\left[\left(\mathrm{A}_{\text {control }}-\mathrm{A}_{\text {sample }}\right) / \mathrm{A}_{\text {control }}\right] \times 100$

\section{Microbiological analysis}

A sample (10g) was taken and aseptically transferred in $90 \mathrm{ml}$ of sterile $0.1 \%$ peptone water to prepare the $10^{-1}$ dilution, from which other decimal dilutions were prepared $\left(10^{-2}, 10^{-3}, 10^{-4}\right.$ and $\left.10^{-5}\right)$. Total plate count was determined using pour plate method on a Plate Count Agar as a medium. Plates were incubated at $35^{\circ} \mathrm{C}$ for $24-48 \mathrm{~h}$ according to (Harrigan and McCance, 1976). Pseudomonas counts were performed using Pseudomonas Isolation Agar medium supplemented with glycerol (Difco, 2009) and incubated at $25^{\circ} \mathrm{C}$ for $48 \mathrm{~h}$. For total Enterobacteriaceae count, violet red bile glucose (VRBG) agar was used as a medium. Plates were incubated at $35^{\circ} \mathrm{C}$ for $48 \mathrm{~h}$ (Difco, 2009). All counts were expressed as $\log \mathrm{CFU} / \mathrm{g}$.

\section{Sensory quality}

Sensory evaluation was performed as described by Tokur et al. (2006). Thawed samples were fried in sunflower oil at $180{ }^{\circ} \mathrm{C}$ for $2.5 \mathrm{~min}$ and then, introduced to the panelists for their assessment. Sensory attributes were evaluated according to their color, odour, taste, texture and overall acceptability on a 1-10 point hedonic scale. The panelists carried out the tests were staff members of Food Technology Department, Suez Canal University and semi-trained panelists.

\section{Statistical analysis}

The obtained data were subjected to Analysis of variance (ANOVA) using SPSS software (version 16.0 
for Windows, SPSS Inc., Chicago). Duncan's multiple range tests were used to locate significance between treatment means at $\mathrm{P} \leq 0.05$.

\section{RESULTS AND DISCUSSION}

Chemical composition, microbiological and chemical quality parameters of catfish mince and raw fish fingers:

The chemical compositions of catfish fillet mince and raw fish fingers are presented in Table 1. The protein and fat contents did not change significantly. Meanwhile, the carbohydrate, moisture and ash contents of fish fingers changed significantly $(\mathrm{P} \leq 0.05)$ because of the presence of coating materials such as flour, starch and bread crumb.

The $\mathrm{pH}$, TVB-N, TMA, FFA, Peroxide value and TBARS values of catfish minced fillet and raw fish fingers are presented in Table 1. The obtained data showed moderate increase in these parameters in fish fingers due to processing of the mince into fish fingers. The $\mathrm{pH}$ value of the raw fish fingers was slightly higher (6.78) than that of catfish minced fillet (6.42). On the other hand, significantly higher values in the FFA, TVB-N and TBARS parameters were observed in the fingers. Similarly, TMA and PV values had the same trend and the increase was not significant.

Table (1) also shows the microbial count of catfish mince and raw fish fingers. Aerobic plate count decreased significantly from 5.96 to $4.52 \log \mathrm{cfu} / \mathrm{g}$ during production process. This may be attributed to the antimicrobial properties of food additives such as garlic (Talab, 2014). However, Pseudomonas and total Enterobacteriaceae bacterial counts in the prepared fingers were lower but not significant. These results are in agreement with the findings of Elyasi et al. (2010), who prepared fish fingers from common carp and found a decrease of all microbiological counts after the production process.

Table (1): Chemical composition, chemical and microbiological quality of catfish mince and raw fish fingers*

\begin{tabular}{|c|c|c|c|}
\hline Analysis & Parameters & Catfish mince & Fish fingers \\
\hline \multirow{5}{*}{$\begin{array}{c}\text { Chemical composition } \\
\text { (\%) }\end{array}$} & Moisture & $76.13^{\mathrm{a}}$ & $72.34^{b}$ \\
\hline & Ash & $1.78^{\mathrm{b}}$ & $2.98^{\mathrm{a}}$ \\
\hline & Crude protein & $19.58^{\mathrm{a}}$ & $19.32^{\mathrm{a}}$ \\
\hline & Crude fat & $1.63^{\mathrm{a}}$ & $1.37^{\mathrm{a}}$ \\
\hline & Carbohydrates & $0.88^{\mathrm{b}}$ & $3.99^{\mathrm{a}}$ \\
\hline \multirow{6}{*}{$\begin{array}{l}\text { Chemical quality } \\
\text { parameters }\end{array}$} & pH & $6.42^{\mathrm{a}}$ & $6.78^{\mathrm{a}}$ \\
\hline & $\begin{array}{c}\text { TVB-N } \\
(\mathrm{mg} / \mathbf{1 0 0 g})\end{array}$ & $9.24^{b}$ & $10.50^{\mathrm{a}}$ \\
\hline & $\begin{array}{c}\text { TMA } \\
(\mathbf{m g} / \mathbf{1 0 0 g})\end{array}$ & $8.54^{\mathrm{a}}$ & $8.96^{\mathrm{a}}$ \\
\hline & $\begin{array}{c}\text { FFA } \\
\text { (g oleic/ } \mathrm{kg}^{-1} \text { lipids) }\end{array}$ & $0.178^{\mathrm{b}}$ & $0.279^{\mathrm{a}}$ \\
\hline & $\begin{array}{c}\mathrm{PV} \\
\left(\mathrm{meq} \mathrm{O} \mathrm{O}_{2} / \mathrm{kg}\right)\end{array}$ & $2.52^{\mathrm{a}}$ & $2.64^{\mathrm{a}}$ \\
\hline & $\begin{array}{c}\text { TBARS } \\
\text { (mg MDA } / \mathrm{kg})\end{array}$ & $0.160^{\mathrm{b}}$ & $0.234^{\mathrm{a}}$ \\
\hline \multirow{3}{*}{$\begin{array}{l}\text { Microbiological quality } \\
\quad(\log \mathrm{CFU} / \mathrm{g})\end{array}$} & APC & $5.96^{\mathrm{a}}$ & $4.52^{\mathrm{b}}$ \\
\hline & Pseudomonas & $2.98^{\mathrm{a}}$ & $2.87^{\mathrm{a}}$ \\
\hline & Enterobacteriaceae & $1.84^{\mathrm{a}}$ & $1.74^{\mathrm{a}}$ \\
\hline
\end{tabular}

*Means within the same column having different superscript letters are significantly different at $\mathrm{P} \leq 0.05$.

\section{Quality parameters of fish finger samples:} Texture:

As shown in Table (2), samples containing transglutaminase (MTGase) showed higher values of texture i.e. its firmness was increased. There was a significant increase in texture values from 1.34 for control to $3.33 \mathrm{~kg} / \mathrm{cm}^{2}$ for MTGase. The increase in the texture values may be attributed to inducing covalent crosslinking of proteins. Ramirez-Suárez et al. (2001) stated that transglutaminase increases cross-linking of myosin heavy chains during setting, thus creating a denser bond network between proteins. The results of Vácha et al. (2006) and Muguruma et al. (2003) confirmed a strong improvement of texture (firmness) after the addition of transglutaminase. It could be noticed that, DSP had lower texture value $\left(1.24 \mathrm{~kg} / \mathrm{cm}^{2}\right)$ compared to control $\left(1.34 \mathrm{~kg} / \mathrm{cm}^{2}\right)$ due to the high fiber content $(51 \%)$ in the added DSP. Sánchez-Alonso et al. (2006) found that addition the wheat dietary fiber to Alaska pollock surimi resulted in a decrease in firmness. 
Table (2): Effect of MTGase and some natural antioxidants on quality parameters of catfish fingers

\begin{tabular}{|c|c|c|c|c|c|c|c|}
\hline Treatments & $\begin{array}{c}\text { Texture } \\
\left(\mathrm{kg} / \mathrm{cm}^{2}\right)\end{array}$ & pH & $\begin{array}{c}\text { TVB-N } \\
(\mathrm{mg} / 100 \mathrm{~g})\end{array}$ & $\begin{array}{c}\text { TMA } \\
(\mathrm{mg} / \mathbf{1 0 0 g})\end{array}$ & $\begin{array}{c}\text { FFA } \\
\text { (g oleic/kg } \mathbf{k g}^{-1} \\
\text { lipids) }\end{array}$ & $\begin{array}{c}\text { PV } \\
(\mathrm{meq} \mathrm{O} \\
/ \mathrm{kg})\end{array}$ & $\begin{array}{c}\text { TBARS } \\
(\mathbf{m g} \\
\text { MDA/kg) }\end{array}$ \\
\hline T1 & $1.34^{\mathrm{c}}$ & $7.05^{\mathrm{a}}$ & $24.48^{\mathrm{a}}$ & $11.14^{\mathrm{a}}$ & $2.58^{\mathrm{a}}$ & $3.19^{\mathrm{a}}$ & $1.33^{\mathrm{a}}$ \\
\hline $\mathbf{T 2}$ & $3.33^{\mathrm{a}}$ & $6.97^{b}$ & $18.92^{\mathrm{b}}$ & $8.03^{b}$ & $1.77^{\mathrm{b}}$ & $1.78^{\mathrm{b}}$ & $0.75^{b}$ \\
\hline T3 & $1.24^{\mathrm{c}}$ & $6.72^{c}$ & $15.77^{\mathrm{d}}$ & $7.38^{\mathrm{c}}$ & $0.79^{d}$ & $1.18^{\mathrm{c}}$ & $0.37^{\mathrm{c}}$ \\
\hline T4 & $1.38^{\mathrm{c}}$ & $6.70^{c}$ & $18.11^{b c}$ & $8.12^{b}$ & $1.26^{\mathrm{c}}$ & $0.48^{\mathrm{d}}$ & $0.33^{c}$ \\
\hline T5 & $2.85^{\mathrm{b}}$ & $6.72^{c}$ & $18.13^{b c}$ & $7.33^{c}$ & $0.87^{\mathrm{d}}$ & $0.99^{c}$ & $0.38^{\mathrm{c}}$ \\
\hline T6 & $3.48^{\mathrm{a}}$ & $6.69^{c}$ & $17.48^{\mathrm{c}}$ & $8.03^{\mathrm{b}}$ & $1.31^{\mathrm{c}}$ & $0.53^{\mathrm{d}}$ & $0.33^{\mathrm{c}}$ \\
\hline
\end{tabular}

T1 Control, T2 Enzyme 0.5\%, T3 Date seed powder (DSP) 1\%, T4 Combination of citric acid $0.5 \%$ and ascorbic acid $0.5 \%$, T5 Combination of date seed powder $1 \%$ and enzyme $0.5 \%$ and T6 Combination of citric acid $0.5 \%$, ascorbic acid $0.5 \%$ and enzyme $0.5 \%$. Means within the same column having different superscript letters are significantly different at $\mathrm{P} \leq 0.05$.

As statistical analysis indicated, frozen storage revealed a significant effect on texture changes during storage period (Table 3). Badii and Howell (2002) reported that increased length of storage time at $-10^{\circ} \mathrm{C}$ hardened the fillets. Dorado-Rodelo et al. (2007) found changes in shear forces for frozen fillets stored at $-20^{\circ} \mathrm{C}$ for 120 days. Makri (2009) related the development of hardness in raw stored frozen fillets to water holding capacity, denaturation and changes of myofibrillar proteins.

Table (3): Effect of frozen storage $\left(-18{ }^{\circ} \mathrm{C}\right.$ for 5 months) on the quality parameters of fish fingers

\begin{tabular}{|c|c|c|c|c|c|c|c|}
\hline $\begin{array}{l}\text { Storage } \\
\text { (month) }\end{array}$ & $\begin{array}{r}\text { Texture } \\
\left(\mathrm{kg} / \mathrm{cm}^{2}\right)\end{array}$ & pH & $\begin{array}{c}\text { TVB-N } \\
(\mathrm{mg} / \mathbf{1 0 0 g})\end{array}$ & $\begin{array}{c}\text { ТМA } \\
\text { (mg/100g) }\end{array}$ & $\begin{array}{l}\text { FFA } \\
\text { (g oleic/kg }{ }^{-1} \\
\text { lipids) }\end{array}$ & $\begin{array}{c}\text { PV } \\
\left(\mathbf{m e q} \mathbf{O}_{2}\right.\end{array}$ & $\begin{array}{c}\text { TBARS } \\
(\mathbf{m g} \\
\text { MDA/kg) }\end{array}$ \\
\hline Zero time & $2.01^{\mathrm{d}}$ & $6.62^{\mathrm{e}}$ & $16.36^{\mathrm{e}}$ & $5.39^{e}$ & $0.55^{\mathrm{e}}$ & $0.56^{\mathrm{d}}$ & $0.25^{\mathrm{c}}$ \\
\hline 1 & $2.06^{\mathrm{d}}$ & $6.67^{\mathrm{de}}$ & $17.31^{\mathrm{de}}$ & $6.77^{d}$ & $0.73^{\mathrm{e}}$ & $0.95^{\mathrm{c}}$ & $0.34^{\mathrm{c}}$ \\
\hline 2 & $2.14^{\mathrm{cd}}$ & $6.73^{d}$ & $18.25^{\mathrm{cd}}$ & $8.17^{\mathrm{c}}$ & $1.21^{\mathrm{d}}$ & $1.20^{\mathrm{bc}}$ & $0.41^{\mathrm{c}}$ \\
\hline 3 & $2.28^{\mathrm{bc}}$ & $6.82^{\mathrm{c}}$ & $19.18^{\mathrm{bc}}$ & $9.30^{\mathrm{b}}$ & $1.43^{c}$ & $1.38^{\mathrm{b}}$ & $0.65^{b}$ \\
\hline 4 & $2.38^{\mathrm{b}}$ & $6.96^{\mathrm{b}}$ & $19.55^{\mathrm{b}}$ & $10.23^{\mathrm{a}}$ & $1.94^{\mathrm{b}}$ & $1.89^{\mathrm{a}}$ & $0.86^{\mathrm{ab}}$ \\
\hline 5 & $2.75^{\mathrm{a}}$ & $7.05^{\mathrm{a}}$ & $22.24^{\mathrm{a}}$ & $10.18^{\mathrm{a}}$ & $2.74^{\mathrm{a}}$ & $2.16^{\mathrm{a}}$ & $1.00^{\mathrm{a}}$ \\
\hline
\end{tabular}

Means within the same column having different superscript letters are significantly different at $\mathrm{P} \leq 0.05$.

\section{Chemical quality changes: pH value}

Changes of $\mathrm{pH}$ value in the treated fish finger samples during 5 months of frozen storage at $\left(-18^{\circ} \mathrm{C}\right)$ are shown in Table (2) and Table (3). The data revealed that there were significant differences $(\mathrm{p} \leq 0.05)$ in $\mathrm{pH}$ values between fish finger treatments along storage periods. It was noticed that the $\mathrm{pH}$ value of the control was higher (7.05) than the other samples. For treatments (Table 2), fish fingers containing MTGase had the highest $\mathrm{pH}$ value (6.97) and fish finger containing citric acid $0.5 \%$, ascorbic acid $0.5 \%$ and enzyme $0.5 \%$ showed the lowest value (6.69). Rostamzad et al. (2011) found that $\mathrm{pH}$ value of treated samples with citric and ascorbic acids were lower than that of control sample in fish fillets during six months of frozen storage. 
The treatments and storage time exhibited a significant effect $(P \leq 0.05)$ on the $\mathrm{pH}$ values of fish fingers. There was comparatively slow increase in $\mathrm{pH}$ vales of fish finger samples during freezing storage period (Table 3). Similar results have been observed by Rathod and Pagarkar (2013) for Pangasius fish cutlets and by Coban (2013) for fish fingers (Sarda sarda). Jay (1996) explained the increase in $\mathrm{pH}$ to the accumulation of metabolites caused by bacterial action in meat. Gill (1983) added that bacteria, on exhaustion of glucose, utilize amino acids (released during protein breakdown) and as a result ammonia accumulates which increases $\mathrm{pH}$ value.

\section{Total volatile basic-nitrogen}

Total volatile basic-nitrogen (TVB-N) is a commonly used chemical method to determine spoilage of fish. The treatments and frozen storage time had a significant effect $(P \leq 0.05)$ on lowering the TVB-N values of fish fingers. The control sample had generally higher TVB-N mean value $(24.48 \mathrm{mg} / 100 \mathrm{~g})$ than the treated samples (Table 2). Fish fingers containing MTGase had the highest mean TVB-N value (18.92 $\mathrm{mg} / 100 \mathrm{~g}$ ) and Fish finger containing DSP had the lowest value $(15.77 \mathrm{mg} / 100 \mathrm{~g})$ among treatments. European Union Commission (1995) reported the legal limits set for these indexes to be $35 \mathrm{mg} / 100 \mathrm{~g}$ for TVBN. Changes in the TVB-N values of fish finger samples during frozen storage are given in Table (3). The values for the prepared fingers did not exceed such limit throughout storage period. Pandey and Kulkarni (2007) reported a significant increase in the TVBN value of fish fingers during frozen storage (6 months). The increasing of TVB-N value during storage is attributed by Chomnawang et al. (2007) to bacterial spoilage and the activity of endogenous enzymes.

\section{Trimethylamine (TMA)}

Trimethylamine nitrogen (TMA) is used as an index to assess the quality and shelf life of seafood products (Hebard et al., 1982). TMA values were statistically lower $(P \leq 0.05)$ in all treated samples compared to the control (Table 2). The treatment containing a combination of date seed powder $1 \%+$ enzyme $0.5 \%$ had the lowest TMA value $(7.33 \mathrm{mg} / 100$ g) followed by The DSP treatment $(7.38 \mathrm{mg} / 100 \mathrm{~g})$, due to the high antioxidant activity of the DSP (42.5\%) as determined in a laboratory assessment. Changes of TMA in treated fish finger samples during 5 months of frozen storage at $-18^{\circ} \mathrm{C}$ are shown in Table (3). The TMA values of all fish finger treatments were gradually increased with increasing storage period.

\section{Free fatty acids (FFA)}

FFA content is a result of enzymatic decomposition of lipid during storage (Tokur et al., 2006). The FFA content in the lipid of a fish is an indication of lipid hydrolysis. The lowest FFA value $\left(0.79 \mathrm{~g} \mathrm{~kg}^{-1}\right.$ lipids $)$ was found in the fish fingers with the addition of DSP, while the highest value in FFA values $\left(2.58 \mathrm{~g} / \mathrm{kg}^{-1}\right.$ lipid, Table 2) was found in the control sample. This is due to the high antioxidant activity of the added DSP (42.5\%). Also, addition of citric and ascorbic acids resulted in a decrease in FFA value compared to control sample. Because ascorbic and citric acids act as oxygen scavengers and metal chelators, thus causing delay in lipid oxidation (Rostamzad et al., 2011).

Changes in the FFA of fish finger samples during frozen storage are given in Table 3. A gradual increase in FFA content with storage duration was observed in all samples. Confirmation of these results was indicated by the results of Pawar et al. (2012) for Catla fish cutlets, Rathod and Pagarkar (2013) for Pangasius fish cutlets and Ninan et al. (2010) for tilapia fish cutlets. Also, Tokur et al. (2006) reported FFA rise from the beginning of storage up to the end of storage.

\section{Peroxide value (PV)}

The peroxide value was employed for determining the formation of primary oxidation products during the storage period. The PV of MTGase treatment was 1.78 meq $\mathrm{O}_{2} / \mathrm{kg}$ which was lower than that of the control (3.19 meq $\mathrm{O}_{2} / \mathrm{kg}$ ). Treatments containing $\mathrm{CA}+\mathrm{AA}$ (T4) and $\mathrm{CA}+\mathrm{AA}+\mathrm{MTGase}(\mathrm{T} 6)$ had the lowest PV values, which were 0.48 and $0.53 \mathrm{meq} \mathrm{O}_{2} / \mathrm{kg}$, respectively. These results are in agreement with those recorded by (Naveena et al., 2008; Taheri et al., 2012) for chicken fillet and fillet due to the antioxidant effects of ascorbic acid in terms of inhibiting lipid oxidation. They also observed that PV value showed a slow increase with frozen storage time. Treatments containing DSP gave 1.18 and $0.98 \mathrm{meq}_{2} / \mathrm{kg}$ for DSP and the combination of DSP + MTGase treatments, respectively. In this concern, Sarkardei and Howel (2008) reported that the increase of peroxide value in samples treated with antioxidants was significantly lower than that of control sample.

Changes in the PV of fish finger samples during frozen storage are given in Table 3. All treatments significantly reduced the PV values throughout storage as compared to the control sample.

\section{The thiobarbituric acid reactive substances (TBARS)}

TBARS values were significantly lower $(P \leq 0.05)$ in all treated samples as compared to the control sample (Table 2). Egyptian Standard (2005) asserted that TBARS value in frozen fish fingers is not to exceed 4.5 mg malonaldehyde/kg. Yanar and Fenercioğlu (1999) reported similar results $(0.6$ and $2.2 \mathrm{mg} \mathrm{MDA} / \mathrm{kg})$ in minced fish meat from carp.

For the variation in treatment's effects, a significant ( $\mathrm{p} \leq 0.05$ ) increase in TBARS value was observed for MTGase treatment $(0.75 \mathrm{mg} \mathrm{MDA} / \mathrm{kg})$ as compared to other treatments. Addition of CA, AA and DSP significantly $(P \leq 0.05)$ decreased TBARS values of prepared fingers, due to their antioxidant effect. This means that usage of CA, AA and DSP had a positive influence on reducing lipid oxidation and, therefore, would enhance shelf-life of fish fingers. Storage time of the prepared catfish fingers had a significant $(P \leq 0.05)$ effect on TBARS values as shown in Table (3). The increase of the TBARS value during frozen storage was affirmed by many researchers (Tokur et al., 2006; İzci, 2010; Boran and Köse, 2007). 
Microbiological changes of fish fingers during frozen storage at $-18^{\circ} \mathrm{C}$ :

\section{Aerobic plate counts (APC)}

Aerobic plate counts (APC) is an indicator of shelflife of food products (Arvanitoyannis et al., 2005). The microbial load of fish fingers depends on the microbial load of the raw fish meat, sanitary conditions, time and temperature of storage as well as other ingredients which are used in preparation of fish fingers. Table (4) shows the microbial content of fish fingers. The APC of control sample increased throughout 5 month at $-18^{\circ} \mathrm{C}$. The increase of APC may be attributed to the increase in simple nitrogenous compounds (amino acids and nucleotides) and fatty acids which were produced by hydrolysis of protein and fat by natural fish enzymes which consequently lead to suitable conditions for bacterial growth. Log APCs of other treatments (T2-T6) were around 4.03- $5.22 \log \mathrm{cfu} / \mathrm{g}$. These levels did not exceed the maximum limits $(7 \log \mathrm{APC} / \mathrm{g})$ set for fresh and frozen fish given by the International Commission on Microbiological Specifications for Foods (1978).

In this study the APCs of the fish fingers were lower than the maximum limits during the storage period. It was observed that the APCs decreased just after addition of DSP, AA and CA, due to their antimicrobial effect. The obtained data also showed that during storage time, the APC counts of fish finger samples were Significantly $(P \leq 0.05)$ increased.

Table (4): Changes of aerobic plate count (APC) $(\log \mathrm{cfu} / \mathrm{g})$ in treated fish fingers (T2-T6) during 5 months of storage at $-18^{\circ} \mathrm{C}$ as compared to the control sample (T1)

\begin{tabular}{|c|c|c|c|c|c|c|c|}
\hline \multirow{2}{*}{ Treatments } & \multicolumn{6}{|c|}{ Storage period (month) } & \multirow{2}{*}{ Mean } \\
\hline & $\mathbf{0}$ & 1 & 2 & 3 & 4 & 5 & \\
\hline T1 & 4.62 & 4.85 & 5.32 & 5.79 & 5.82 & 5.95 & $5.39^{\mathrm{a}}$ \\
\hline $\mathbf{T} 2$ & 4.61 & 4.83 & 4.95 & 5.39 & 5.69 & 5.83 & $5.2^{\mathrm{b}}$ \\
\hline T3 & 3.54 & 3.72 & 3.85 & 4.23 & 4.63 & 4.80 & $4.13^{\mathrm{d}}$ \\
\hline $\mathbf{T 4}$ & 3.52 & 3.82 & 4.11 & 4.25 & 4.52 & 4.83 & $4.19^{\text {cd }}$ \\
\hline T5 & 3.53 & 3.69 & 3.76 & 4.15 & 4.27 & 4.78 & $403^{\mathrm{e}}$ \\
\hline T6 & 3.51 & 3.71 & 4.21 & 4.48 & 4.64 & 4.87 & $4.24^{\mathrm{c}}$ \\
\hline Mean & $3.90^{\mathrm{f}}$ & $4.10^{\mathrm{e}}$ & $4.37^{\mathrm{d}}$ & $4.72^{\mathrm{c}}$ & $4.93^{b}$ & $5.18^{\mathrm{a}}$ & \\
\hline
\end{tabular}

T1 Control, T2 Enzyme 0.5\%, T3 Date seed powder (DSP) 1\%, T4 Combination of citric acid 0.5\% and ascorbic acid 0.5\%, T5 Combination of date seed powder $1 \%$ and enzyme $0.5 \%$ and T6 Combination of citric acid $0.5 \%$, ascorbic acid $0.5 \%$ and enzyme $0.5 \%$.

Means within the same column having different superscript letters are significantly different at $\mathrm{P} \leq 0.05$ for treatments, while means within the same row having different superscript letters are significantly different for time of storage.

\section{Pseudomonas}

Pseudomonas spp count in fish samples is of highly importance because this bacterium can be used as an indicator of food quality as spoilage organism (Jeya Sekaran et al., 2006 and Yagoub, 2009). Table (5) shows Pseudomonas count in treated fish finger samples during 5 months of frozen storage. At zero time, the Pseudomonas count of control was $2.21 \mathrm{log} \mathrm{cfu} / \mathrm{g}$ and reached $3.11 \mathrm{log} \mathrm{cfu} / \mathrm{g}$ at the end of storage. However, Log Pseudomonas of other treatments (T2-T6) ranged from 1.78 to $2.20 \mathrm{cfu} / \mathrm{g}$. Enzyme treatment (T2) didn't show any significant difference In Pseudomonas count as compared to control. This means that the enzyme had no antimicrobial effect. Treatment combination of citric acid, ascorbic acid and enzyme had the lowest Pseudomonas count mean (2.06 log $\mathrm{cfu} / \mathrm{g}$ ) compared to other treatments and control $(2.71 \log \mathrm{cfu} / \mathrm{g})$, because their antimicrobial action. Pseudomonas counts decreased at the second month of the storage then increased through storage time. Gram and Melchiorsen
(1996) found that Pseudomonas spp. counts increased as the storage time increased.

\section{Total Enterobacteriaceae}

Enterobacteriaceae counts in fish finger samples are shown in Table (6). Total Enterobacteriaceae counts in fish finger samples at the zero time ranged from 0.53 to $0.65 \log \mathrm{cfu} / \mathrm{g}$. Enterobacteriaceae mean counts in fish finger samples ranged from $0.94-1.12(\log \mathrm{cfu} / \mathrm{g})$. DSP treatment sample had the lowest Enterobacteriaceae count as compared to other treatments and control. Also, addition of citric and ascorbic acids led to a decrease in Enterobacteriaceae count of fish fingers. Enterobacteriaceae levels permitted by Center for Food Safety (2014) are $<10^{2}$ $\mathrm{CFU} / \mathrm{g}$ for ready-to-eat food; therefore, counts are within the acceptable limits for frozen fish products. For all studied samples, the Enterobacteriaceae counts were within the acceptable limits. Thus, the prepared fish fingers were proper from the hygienic point of view. 
Table (5): Changes of Pseudomonas count (log cfu/g) in treated fish finger (T2-T6) during 5 months of storage at $18^{\circ} \mathrm{C}$ as compared to the control sample (T1)

\begin{tabular}{|c|c|c|c|c|c|c|c|}
\hline \multirow{2}{*}{ Treatments } & \multicolumn{6}{|c|}{ Storage period (month) } & \multirow{2}{*}{ Mean } \\
\hline & $\mathbf{0}$ & 1 & 2 & 3 & 4 & 5 & \\
\hline T1 & 2.21 & 2.36 & 2.74 & 2.2 & 2.94 & 3.11 & $2.71 \mathrm{a}$ \\
\hline $\mathbf{T} 2$ & 2.20 & 2.32 & 2.58 & 2.81 & 2.92 & 3.02 & $2.64 \mathrm{a}$ \\
\hline T3 & 1.84 & 1.90 & 2.14 & 2.35 & 2.47 & 2.64 & $2.22 \mathrm{bc}$ \\
\hline T4 & 2.01 & 2.21 & 2.32 & 2.43 & 2.52 & 2.61 & $2.35 b$ \\
\hline T5 & 1.83 & 1.87 & 2.23 & 2.36 & 2.40 & 2.54 & $2.21 \mathrm{c}$ \\
\hline T6 & 1.98 & 1.07 & 2.37 & 2.55 & 2.62 & 1.76 & $2.06 \mathrm{~d}$ \\
\hline Mean & $2.01 \mathrm{c}$ & $1.96 \mathrm{c}$ & $2.40 \mathrm{~b}$ & $2.57 \mathrm{a}$ & $2.65 \mathrm{a}$ & $2.61 \mathrm{a}$ & \\
\hline
\end{tabular}

T1 Control, T2 Enzyme $0.5 \%$, T3 Date seed powder (DSP) 1\%, T4 Combination of citric acid $0.5 \%$ and ascorbic acid $0.5 \%$, T5 Combination of date seed powder $1 \%$ and enzyme $0.5 \%$ and T6 Combination of citric acid $0.5 \%$, ascorbic acid $0.5 \%$ and enzyme $0.5 \%$.

Means within the same column having different superscripts are significantly different at $\mathrm{P} \leq 0.05$ for treatments, while Means within the same row having different superscripts are significantly different for time of storage.

Table (6): Changes of Enterobacteriaceae count (log cfu/g) in treated fish fingers (T2-T6) during 5 months of storage at $-18^{\circ} \mathrm{C}$ as compared to the control sample (T1)

\begin{tabular}{|c|c|c|c|c|c|c|c|}
\hline \multirow{2}{*}{ Treatments } & \multicolumn{6}{|c|}{ Storage period (month) } & \multirow{2}{*}{ Mean } \\
\hline & $\mathbf{0}$ & 1 & 2 & 3 & 4 & 5 & \\
\hline T1 & 0.65 & 0.88 & 0.98 & 1.28 & 1.45 & 1.50 & $1.12^{\mathrm{a}}$ \\
\hline $\mathbf{T 2}$ & 0.64 & 0.83 & 0.87 & 0.93 & 1.40 & 1.54 & $1.04^{\mathrm{b}}$ \\
\hline T3 & 0.53 & 0.72 & 0.82 & 1.02 & 1.20 & 1.33 & $0.94^{\mathrm{c}}$ \\
\hline T4 & 0.57 & 0.76 & 0.98 & 1.21 & 1.30 & 1.35 & $1.03^{b}$ \\
\hline T5 & 0.54 & 0.73 & 0.83 & 0.92 & 1.30 & 1.38 & $0.95^{\mathrm{c}}$ \\
\hline T6 & 0.56 & 0.78 & 0.85 & 0.96 & 1.32 & 1.54 & $1.00^{\mathrm{b}}$ \\
\hline Mean & $0.58^{f}$ & $0.78^{\mathrm{e}}$ & $0.89^{\mathrm{d}}$ & $1.05^{\mathrm{c}}$ & $1.33^{\mathrm{b}}$ & $1.44^{\mathrm{a}}$ & \\
\hline
\end{tabular}

T1 Control, T2 Enzyme 0.5\%, T3 Date seed powder (DSP) 1\%, T4 Combination of citric acid 0.5\% and ascorbic acid $0.5 \%$, T5 Combination of date seed powder $1 \%$ and enzyme $0.5 \%$ and T6 Combination of citric acid $0.5 \%$, ascorbic acid $0.5 \%$ and enzyme $0.5 \%$.

Means within the same column having different superscripts are significantly different at $\mathrm{P} \leq 0.05$ for treatments, while means within the same row having different superscripts are significantly different for time of storage.

\section{Sensory changes of fish fingers:}

The acceptability of fish and fishery products during storage depends on changes in their sensory attributes. The sensory parameters of fish finger samples prepared from catfish were evaluated in terms of color, odour, taste, texture, and overall acceptability (Figure 1). In this study, the panelists evaluated color of fish fingers meat not the external layer. As data indicated, all fish finger treatments and frozen storage had a significant effect on color changes during storage time. Scores of color decreased when the storage time increased. It is clear to notice that the MTGase sample had the highest color value as compared to the control and other samples. 
It was found that treatments and storage time had a statistically significant effect $(P \leq 0.05)$ on odour scores of fish fingers. Starting from the fourth month, scores of the odour for all treatments gradually decreased throughout storage period, but there was a significant difference in odour between the fourth and fifth month. Treatment containing a combination of citric acid, ascorbic acid and MTGase had the highest odour values compared to other treatments throughout storage period. At the end of storage, the control sample had the lowest odour scores (7.11) compared to treated fish finger samples. Similar results were obtained by Pourashouri et al. (2009) for catfish fillet treated with AA and CA.

The MTGase treatment had the highest taste scores compared to other treatments and control. Scores of taste increased during the first and second months then started to decrease at the fourth month even the end of storage.

The MTGase treatment had the highest texture scores and Treatment containing citric acid and ascorbic acid had the lowest texture scores. There was a slight decrease in texture scores throughout storage period.

At zero time, the overall acceptability score of control was 8.72 and reached a score of 8.06 at the end of storage. The MTGase treatment demonstrated the highest overall acceptability score compared to other treatments. Adding natural antioxidants in ready-to-eat fish products prevented or reduced lipid oxidation and preserved sensory attributes of such products (Yanishlieva et al., 2006; Naveena et al., 2008).
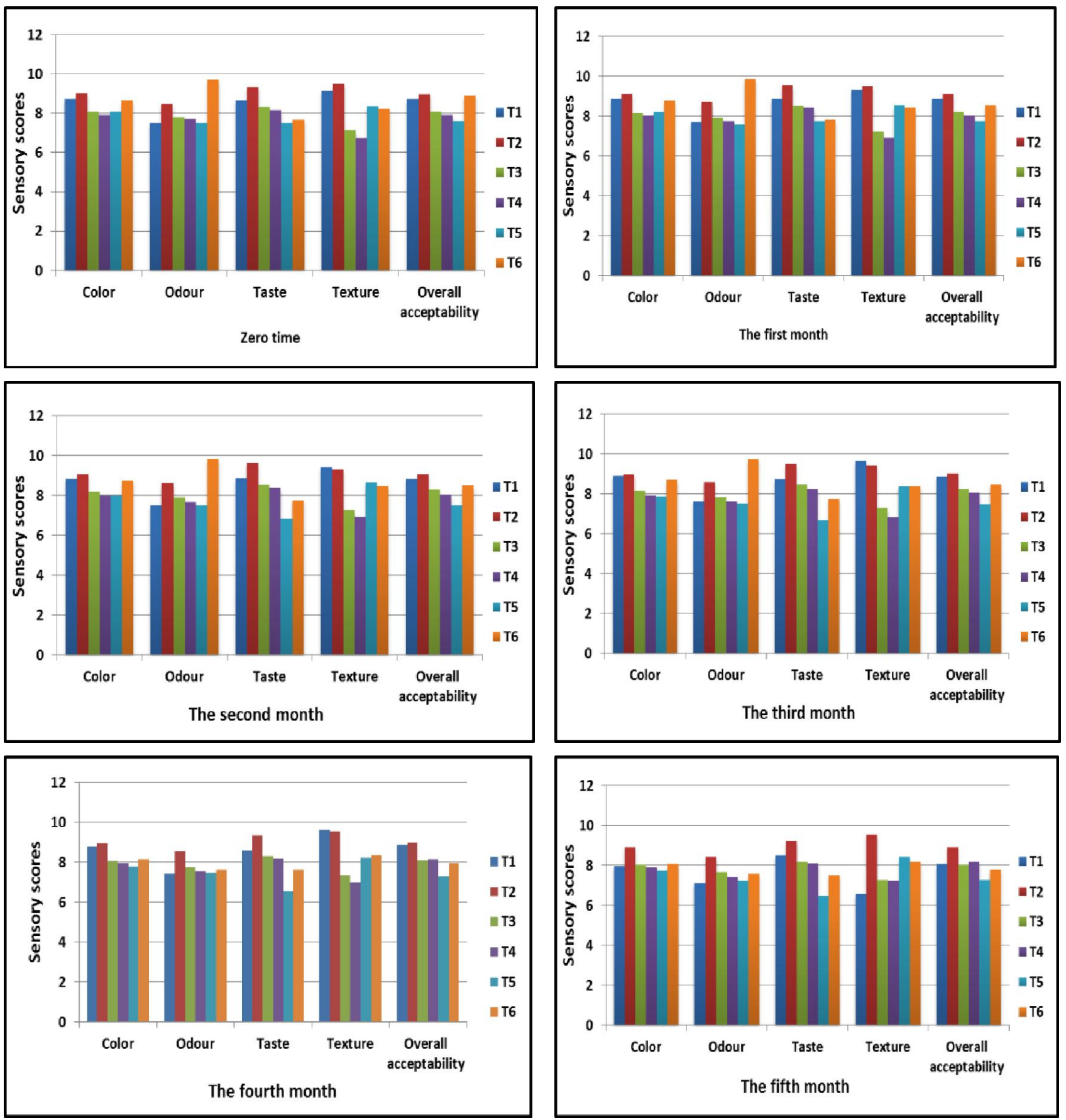

Figure (1): Changes in sensory scores of fish finger samples during the frozen storage period at $-18^{\circ} \mathrm{C}$. 


\section{CONCLUSION}

Acceptable fish fingers can be produced from catfish by using some natural additives like date seed powder, citric acid and ascorbic acid. Also, date seed powder treatment was more effective in improving the chemical, microbiological and sensory properties of the prepared fingers than other studied treatments. Moreover, addition of MTGase enzyme, especially in combinations with other tested additives, resulted in improving in textural and sensory properties of prepared fish fingers.

\section{REFERENSES}

Al-Farsi, M., C. Alasalvar, M. Al-Abid, K. Al-Shoaily, M. Al-Amry and F. Al-Rawahy (2007). Compositional and functional characteristics of dates, syrups, and their by-products. Food Chemistry, 104(3): 943-947.

Ammar, A. S. and R. A. Habiba (2010). Phenolic content and antioxidant activity of date seeds. Journal of Agricultural and Veterinary Sciences, Qassim University, 3(1): 3-8.

AOAC (2000). Official Methods of Analysis. $17^{\text {th }}$ ed. Association of Analytical Chemists, procedure. Washington, DC.

Arvanitoyannis, I. S., E. V. Tsitsika and P. Panagiotaki (2005). Implementation of quality control methods (physicochemical, microbiological and sensory) in conjunction with multivariate analysis towards fish authenticity. International Journal of Food Science and Technology, 40: 37-263.

Aubourg, S., F. Pérez -Alonso and J. M. Gallardo (2004). Studies on rancidity inhibition in frozen horse mackerel (Trachurus trachurus) by citric and ascorbic acids. European Journal of Lipid Science and Technology, 106: 232-240.

Babovic, N., I. Zizovic, S. Saicic, J. Ivanovic and S. Petrovic (2010). Oxidative stabilization of Sunflower oil by antioxidant fractions from selected Lamiaceae herbs. Chemical Industry and Chemical Engineering Quarterly, 16 (4): $287-$ 293.

Badii, F. and N. K. Howell (2002). Changes in the texture and structure of cod and haddock fillets during frozen storage. Food hydrocolloids, 16(4): 313-319.

Banerjee, S. (2006). Inhibition of mackerel (Scomber scombrus) muscle lipoxygenase by green tea polyphenols. Food Research International, 39: 486-491.

Benjakul, S., W. Visessanguan, V. Phongkanpai and M. Tanaka (2005). Antioxidative activity of caramelisation products and their preventive effect on lipid oxidation in fish mince. J. Food Chem., 90: 231-239.

Bligh, E. G. and W. J. Dyer (1959). A rapid method of total lipid extraction and purification. Canadian Journal of Physiology and Pharmacology, 37: 911-917.

Bochi, V. C., J. Weber, C. P. Ribeiro, A. M. Victörio and F. Emanuelli (2008). Fish burgers with silver catfish (Rhamdia quelen) filleting residue. Bioresource Technology, 99: 8844-8849.

Boran, M. and S. Köse (2007). Storage properties of three types of fried whiting balls at refrigerated temperatures. Turkish Journal of Fisheries and Aquatic Sciences, 7: 65-70.

Cakli, S., L. Taskaya, D. Kisla, U. Celik, C. A. Ataman, A. Cadun, B. Kikinc and R. Haji Maleki (2005). Production and quality of fish fingers from different fish species. European Food Research and Technology, 220(5-6): 526-530.

Centre for Food Safety (2014). Microbiological Guidelines for Food (For ready-to-eat food in general and specific food items). Centre for Food Safety, Food and Environmental Hygiene Department 43/F, Queensway Government Offices, 66 Queensway, Hong Kong.

Chomnawang, C., K. Nantachai, J. Yongsawatdigul, S. Thawornchinsombut and S. Tungkawachara (2007). Chemical and biochemical changes of hybrid catfish fillet stored at $4^{\circ} \mathrm{C}$ and its gel properties. Journal of Food Chemistry, 103: 420427.

Coban, E. O. (2013). Effect of ginger oil on the sensory and chemical changes of fish finger (Sarda sarda, Heckel 1843) during refrigerated storage. International Food Research Journal, 20 (4):1575-1578.

Colombo, J., K. N. Kannass, D. J. Shaddy, S. Kundurthi, J. M. Maikranz, C. J. Anderson, O. M. Blaga and S. E. Carlson (2004). Maternal DHA and the development of attention in infancy and toddlerhood. Child Development, 75: 12541267.

Difco and BBL Manual (2009). Manual of Microbiological Culture Media. Zimbro MJO, Power DA, Miller ShM, Wilson GE and Julie A, Johnson BA (Eds.). $2^{\text {nd }}$ edition. Maryland. USA.

Dorado-Rodelo, J. A., J. M. Ezquerra-Brauer and H. Soto-Valdez (2007). Effect of oven proof plastic films on the quality of spotted rose snapper fillets during frozen storage. Packag. Technol. Sci, 20: 301-307.

Egan, H., R. S. Krik and R. Sawyer (1997). Pearson's chemical analysis of food, $9^{\text {th }}$ Ed., 609-634.

Egyptian Standard Specifications (2005). Quick frozen fish products breaded or in batter. ES 3495/2005.

Elyasi, A., E. Zakipour Rahim Abadi, M. A. Sahari and P. Zare (2010). Chemical and microbial changes of fish fingers made from mince and surimi of Common Carp. International Food Research Journal, 17: 915-920.

Emborg, J., B. G. Laursen, T. Rathjen and P. Dalgaard (2001). Microbial spoilage and formation of biogenic amines in fresh and thawed modified atmosphere packed Salmon (Salmon salar) at $2^{\circ} \mathrm{C}$. Journal of Applied Microbiology, 92: 790799.

European Union Commission (1995). decision 95/149/EC, 8 March 1995. Off J Eur Commun L97:84-87. 
Gill, C.O. (1983). Meat spoilage and evaluation of the potential storage life of fresh meat. Journal of Food Protection, 46: 444-452.

Giosafatto, C. V. L., N. M. Rigby, N. Wellner, M. Ridout, F. Husband and A. R. Mackie (2012). Microbial transglutaminase-mediated modification of ovalbumin. Food Hydrocoll, 26:261-267.

Gram, L. and J. Melchiorsen (1996). Interaction between fish spoilage bacteria Pseudomonas sp. and Shewanella putrefaciens in fish extracts and on fish tissue. Journal of Applied Bacteriology, 80(6): 589-595.

Harrigan, W. F. and M. E. McCance (1976). Laboratory methods in food and dairy microbiology. Academic Press, London.

Hebard, C. E., G. J. Flick and R. E. Martin (1982). Occurrence and significant of tri methyl amine oxide and it derivatives in fish and shellfish. In: chemistry and biochemistry of marine food products, Martin, R.E., et al., (Editors), Connecticut, AVI publishing co., pp: 149-304.

ICMSF (1978). Microorganisms in foods. The International Commission on Microbiological Specifications for Foods, Toronto, Canada (vol 2).

Iso, H., M. Kobayashi, J. Ishihara, S. Sasaki, K. Okada, Y. Kita, Y. Kokubo and S. Tsugane (2006). Intake of fish and n-3 fatty acids and risk of coronary heart disease among Japanese. Circulation, 113: 195-202.

İzci, L. (2010). Utilization and quality of fish fingers from prussian carp (Carassius gibelio Bloch, 1782). Pakistan Veterinary Journal, 30(4): $207-$ 210.

Jay, J. M. (1996). Antioxidant. In: Modern Food Microbiology. 4th Ed. CBS Publishers and Distributors, New Delhi, 265-266.

Jeyasekaran, G., P. Ganesan, R. Anandaraj, R. Jeya Shakila and D. Sukumar (2006). Quantitative and qualitative studies on the bacteriological quality of Indian white shrimp (Penaeus indicus) stored in dry ice. J. Food Microbiol., 23(6): 526-533.

Karakaya, M., E. Bayrak and K. Ulusoy (2011). Use of natural antioxidants in meat and meat products. Journal of Food Science and Engineering, 1: 110.

Kim, S., K. Lee, J. Park, H. Lee and I. Hwang (2006). Effect of natural antioxidants on stored freezedried food product formulated using horse mackerel (Trachurus trachurus). J. Sci. and Tech., 41: 90-95.

Lee, S. C., J. H. Kim, S. M. Jeong, D. R. Kim, J. U. Ha and K. C. Nam (2003). Effect of far infrared radiation on the antioxidant activity of rice hulls. Journal of Agricultural and Food Chemistry, 51: 4400-4403.

Makri, M. (2009). Full Length Research Paper Biochemical and textural properties of frozen stored $\left(-22^{\circ} \mathrm{C}\right)$ gilthead sea bream (Sparus aurata) fillets. African Journal of Biotechnology, 8(7).
Malle, P. and M. Poumeyrol (1989). A new chemical criterion for the quality control of fish: trimethylamine/total volatile basic nitrogen $(\%)$. Journal of Food Protection, 52: 419-423.

Malle, P. and S. H. Tao (1987). Rapid quantitative determination of trimethylamine using steam distillation. Journal of Food Protection, 50: 756760.

Motoki, M. and K. Seguro (1998) Transglutaminase and its use for food processing. Trends Food Sci. Technol., 9: 204-210.

Muguruma, M., K. Tsuruoka, K. Katayama, Y. Erwanto, S. Kawahara, K. Yamauchi and T. Soeda (2003). Soybean and milk proteins modified by transglutaminase improves chicken sausage texture even at reduced level of phosphate. Meat Science, 63(2): 191-197.

Naveena, B. M., A. R. Sen, R. P. Kingsly, D. B. Singh and N. Kondaiah (2008). Antioxidant activity of pomegranate rind powder extract in cooked chicken patties. Int. J. Sci. Technol, 43: 18071812.

Nelson, J. S. (2006). Fishes of the World. John Wiley and Sons, Inc. Canada.

Ninan, G., J. Bindu and J. Joseph (2010). Frozen storage studies of value added mince based products from tilapia (Oreochromis mossambicus, Peters 1852). Journal of Food Processing and Preservation, 34: 255-271.

Pandey, B. N. and G. K. Kulkarni (2007). A study on the deep frozen fish cutlets and fingers prepared from different carp species. Fisheries and Fish Toxicology, 75 - 90.

Pawar, P. P., A. U. Pagarkar, N. B. Rathod, T. E. Baug and M. A. Rather (2012). Standardisation of recipe for fish cutlet product from fresh water fish Catla (Catla catla). European Journal of Experimental Biology, 2 (6): 2043-2048.

Pourashouri, P., B. Shabanpour, P. Auburg, J. Daghigh Rohi and A. Shabani (2009). An investigation of rancidity inhibition during frozen storage of wels catfish (Silurus glanis) fillets by previous ascorbic and citric acid treatment. International Journal of Food Science and Technology, 44 (8): 1503-1509.

Rahman, M. S., S. Kasapis, N. S. Z. Al-Kharusi, I. M. Al-Marhubi and A. J. Khan (2007). Composition characterisation and thermal transition of date pits powders. Journal of food engineering, 80(1): $1-10$.

Ramirez-Suárez, J. C., Y. L. Xiong and B. Wang (2001). Transglutaminase cross-linking of bovine cardiac myofibrillar proteins and its effect on protein gelatin. Journal of Muscle Foods, 12: 8596.

Rathod, N. and A. Pagarkar (2013). Biochemical and sensory quality changes of fish cutlets, made from Pangasius fish (Pangasianodon hypophthalmus) during storage in refrigerated display unit $\left(-15\right.$ to $\left.-18^{\circ} \mathrm{C}\right)$. International Journal of Food, Agriculture and Veterinary Sciences $3(1): 1-8$ 
Rostamzad, H., B. Shabanpour, M. Kashaninejad and A. Shabani (2011). Antioxidative activity of citric and ascorbic acids and their preventive effect on lipid oxidation in frozen Persian sturgeon fillets. Latin American applied research, 41(2): 135.

Sánchez-Alonso, I., R. Haji-Maleki and A. J. Borderías (2006). Effect of wheat fiber in frozen stored fish muscular gels. European Food Research and Technology, 223(4): 571-576.

Sarkardei, S. and N. Howell (2008). Effect of natural antioxidants on stored freeze dried food product formulated using horse mackerel (triachurus trachurus). Journal of Food Science and Technology, 43: 309-315.

Serdaroğlu, M. and E. Felekoglu (2005). Effects of using rosemary extract and onion juice on oxidative stability of sardine (Sardina pilchardus) mince. Journal of Food Quality, 28(2): 109-120.

Simopoulos, A. P. (1999). Essential fatty acids in health and chronic disease. The American journal of clinical nutrition, 70 (3): 560-569.

Sinn, N., C. M. Milte, S. J. Street, J. D. Buckley, A. M. Coates, J. Petkov and P. R. Howe (2012). Effects of n-3 fatty acids, EPA v. DHA, on depressive symptoms, quality of life, memory and executive function in older adults with mild cognitive impairment: a 6-month randomised controlled trial. British Journal of Nutrition, 107(11): 16821693.

Tadpitchayangkoon, P. and J. Yongsawatdigul (2009). Comparative study of washing treatments and alkali extraction on gelation characteristics of striped catfish (Pangasius hypophthalmus) muscle protein. Journal of food science, 74(3): C284-C291.
Taheri, S., A. A. Motalebi and A. Fazlara (2012). Antioxidant effect of ascorbic acid on the quality of cobia (Rachycentron canadum) fillets during frozen storage. Iranian journal of fisheries sciences, 11(3): 666-680.

Talab, A. S. (2014). Effect of cooking methods and freezing storage on the quality characteristics of fish cutlets. Adv J Food Sci Technol. 6: 468-479.

Tarladgis, B. G., B. M. Watts and M. Yonathan (1960). Distillation method for the determination of malonaldehyde in rancid foods. Journal of American Oil Chemistry Society, 37(1): 44-48.

Tokur, B., S. Ozkütük, E. Atici G. Ozyurt and C. E. Ozyurt (2006). Chemical and sensory quality changes of fish fingers, made from mirror carp (Cyprinus carpio L, 1758), during frozen storage $\left(-18^{\circ} \mathrm{C}\right)$. Food Chemistry, 99(2): 335-341.

Vácha, F., I. Novik, J. Spicka and M. Podola (2006). Determination of the effect of microbial transglutaminase on technological properties of common carp (Cyprinus carpio L.) meat. Czech Journal of Animal Science, 51(12): 535.

Venugopal, V. and F. Shahidi (1995). Value added products from underutilized fish species. Food Science and Nutrition, 35:431-453.

Yagoub, S.O. (2009). Isolation of Enterobacteriaceae and Pseudomonas spp. from raw fish sold in fish market in Khartoum state. Journal of Bacteriology Research, 1 (7): 085-088.

Yanar, Y. and H. Fenercioglu (1999). The utilization of carp (Cyprinus carpio) flesh as fish ball. Turkish Journal of Veterinary and Animal Sciences, 23 (4): $361-366$

Yanishlieva, N. V., E. Marinova and J. Pokorný (2006). Natural antioxidants from herbs and spices. European Journal of lipid science and technology, 108 (9): 776-793.

\section{تأثير إنزيم الترانس جلوتامينيز وبعض مضادات الأكسدة الطبيعية على جودة أصابع القراميط الجاهز للأكل

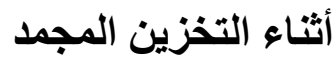 \\ سمر عارف "، نها مرسىى ، رمضان احمد عبد الغنى حبيبة'، فاطمة محمد محمود زايط'

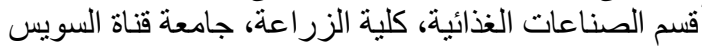

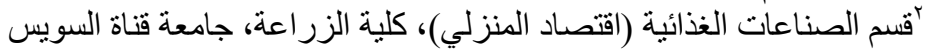

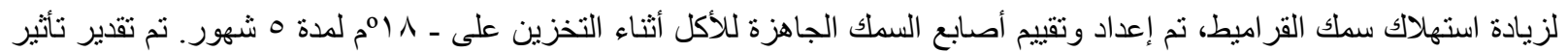

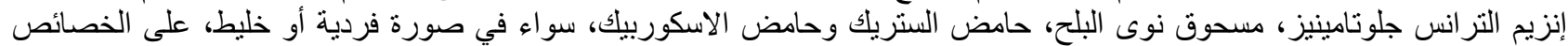

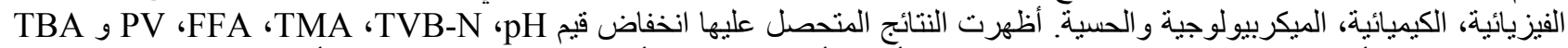

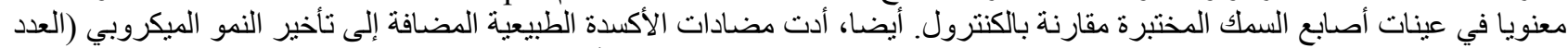
البكتيري الكلى (Enterobacteriaceae Pseudomonas) خلال فلت فترة التخزين، و أعطت العينات المختبرة نتائج جيدة مقارنة بالكنترول.

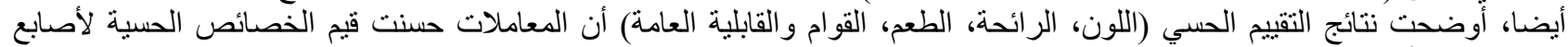
السمك المعدة أثناء التخزين المجمد مقارنة بالكنترول. الكلمات الدالة المرشدة: أصابع السمك الجاهزة للأكل، إنزيم الترانس جلوتامينيز، مسحوق نوى البلح، حامض الستريك، حامض الاسكوربيك 